doi: 10.17492/pragati.v3i2.7741

\title{
Macro-trends in Steel Industry in India: Implications for Risk
}

\author{
Minakshi Choudhary*
}

\begin{abstract}
This paper presents a macro level analysis of steel industry. We have estimated the growth trend for production, consumption, exports and imports at the economy level by using a semi-log equation model. Firstly, we found that all variables are significantly related to a catch-all variable called 'time'. Secondly, we calculated the predicted value of all variables and compared them with the actual value by the graphic presentations. They closely follow each other in most cases. The regression analysis shows that production grew at 8\% and consumption at 7.75 during the time period 1992-2015. Exports grew at $9.78 \%$ per annum and declined drastically after the year 2005. On the other hand, the imports grew at $10.53 \%$ and increased also drastically after 2005. It shows that after the year 2005, there could have been a change in the industrial policy. On the whole we concluded that production and consumption increased over the time. Exports and imports show an increasing trend but export trend is weaker than the import trend. This shows that systematic risk arises due to transaction exposure of volatility in foreign exchange because we earned less Foreign Exchange (FE) and spent more on steel import in the form of Foreign Exchange. Since the time when FE rate regime has been liberalised the FE rates have been very volatile and Rupee has been depreciating constantly. If a larger sum is spent on imports it implies that the foreign exchange risk is higher. But since this is systematic risk it cannot be diversified.
\end{abstract}

Keywords: Semi-log growth equation; Steel industry; Export of steel; Systematic risk.

\subsection{Introduction}

Steel industry is a traditionally heavy industry which had been dominated by the public sector. It was only after liberalization, in 1991 that decontrol of this industry happened. This implied many things. In the era of control, the consumption was restricted; there was a license system for buying steel in bulk. Therefore, consumption was to made match production. This led to a restrictive business environment in the industry.

*Assistant Professor, Sri Aurobindo College (Day), University of Delhi.

(email: menu_tohana@yahoo.com) 
After policy of liberalization, financial management of steel industry too was liberalised. The economy opened up to the external sector; trade was liberalised and tariffs were reduced. In the absence of licensing, new steel firms could be set-up. All of this led to the growth of steel industry. Steel industry saw more competition between public and private sectors and this led to a further environment of risk. The opening of the external sector had implications for the pattern of import and export because of domestic consumption and production. The increase in the steel industry's exposure to foreign markets gave rise to foreign exchange risk which added to the existing risk.

We need to understand the macro picture for realising the significance of systematic risk. Hence, our first level of analysis consists of the study of production, consumption, export and import by analysing the macro level. In this section, we will calculate the annual compound growth rate (ACGR) of steel industry from 1992 to 2015 (after decontrol) over the time period of 24 years by using semi-log regression model. There are four variables (production, consumption, export and import) and one independent variable (year) for all respective dependent variables. For ACGR firstly, we will calculate the instantaneous growth rate (for all respective variables) by taking log both side, then calculate the exponential value of instantaneous growth rate and subtract one from this value and multiply by 100 . Now we find ACGR for all respective dependent variables over the time. Secondly, we calculate the predicted value of all dependent variables by taking the exponential value of log value of respective variables and compare them with actual variables by graph.

\subsection{Review of Literature}

Panday (2008) observes a particular trend in the steel industry. He found that per capita consumption and exports have also been gone up with the LPG era (liberalization, privatization and globalization). He showed that due to availability of raw material and low costs manpower, the Indian steel industry was in the growth stage, and this trend will be continue for next several years. Bhandari, Firoz, Mundhe and Jaitly (2009) show that economic growth of India is contingent upon the growth of the Indian steel industry and steel consumption is also taken to be an indicator of economic development. They find that production of steel in India has increased by a compounded annual growth rate (CAGR) of 8 percent during the period 2002-03 to 2006-07.

Firoj (2014) shows that all nations from their industrialization history have been supported by a strong steel industry of their own. From construction, industrial machinery to consumer products, steel finds a wide variety of applications. He finds that steel industry is characterized by high capital intensity, high dependence on bulk raw 
materials, cyclical growth trends, perpetual over-capacity and relatively low profitability. He also shows that the problems associated with the steel industry are generally complex requiring larger governmental and social interventions for its sustainable growth.

Kulkarni (2015) gives a brief report on iron and steel industry in India. $\mathrm{He}$ explains the growth in production, consumption, exports, imports, investment, and sales in steel industry. He focuses on the New National Steel Policy, 2005. Parmila, Kumar and Karmakar (2016) show that New Industrial policy opened up the Indian iron and steel industry for private investment by removing it from the list of industries reserved for public sector and exempting it from compulsory licensing. Imports of foreign technology as well as foreign direct investment are now freely permitted up to certain limits under an automatic route. They show that Ministry of Steel plays the role of a facilitator, providing broad directions and assistance to new and existing steel plants, in the liberalised scenario. They also show that the rapid and stable growth of the demand side has also prompted domestic entrepreneurs to set up fresh greenfield projects in different states of the country from the last few years.

\subsection{Data and Methodology}

Since 1991 when economic reforms were initiated by the government, we have seen new dimensions of industrial growth particularly in steel industry. Licensing requirement to increase capacity has been abolished. Steel industry has been removed from the list of industries reserved for the public sector and has an approval of foreign equity investment upto $100 \%$ automatically. Price and distribution controls have been removed from Jan. 1992. Restrictions on external trade, both in import and export have been removed. Import duty rates have been reduced drastically.

We collected the aggregate data from MS (Ministry of Steel) and JPC (Joint Plant Committee). There are four aggregate variables which we have used in growth analysis.

(i) Production: (alloy + non-alloy): This is the large share of the main and other producers in total finished production for sale. It is largely due to substantial availability of raw materials as well as expansion of capacities and emergence of new units.

(ii) Consumption: Real Consumption is obtained from apparent consumption (production + imports - exports +/- variation in stocks) of total finished steel after adjusting for double counting in flat products.

(iii) Export: India started exporting steel way back in 1964, as exports were not restricted largely on domestic surpluses. Therefore, after liberalization, export of steel has been increased drastically. Subsequently, the rapid growth of domestic steel demand has led to a decline in the rate of growth exports as India ensured that her domestic requirements are 
adequately met.

(iv) Import: Steel products were free to be imported; the advance licensing scheme allowed duty free import of raw material for export.

\subsection{Methodology for Macro-level analysis}

We have analysed the trends and growth of steel industry by using semi-log regression model at economy level during 1992 to 2015 (after decontrol policy). We have calculated the Annual Compound Growth Rate (ACGR) of the four variables (production, consumption, export and import).

Semi-log Growth Equation: The growth rate has been calculated by using the semi-log regression function, which is the best for determining growth rates.

$$
\begin{aligned}
& \log Y t=a+b^{*} t \\
& \log Y(t-1)=a+b^{*}(t-1)
\end{aligned}
$$

Subtracting equation (2) from (1)

$$
\log \mathrm{t}-\log (\mathrm{t}-1)=\mathrm{b}
$$

Or $\quad \log (\mathrm{Yt} / \mathrm{Y}(\mathrm{t}-1))=\mathrm{b}$

Hence, $\mathrm{b}$ is measure of the relative change of $\mathrm{Y}$ over time and it is the exponential growth rate.

And now,

$$
\mathrm{Yt}=\mathrm{Y} 0(1+\mathrm{r})^{\mathrm{t}}
$$

Taking $\log$ on both sides,

$$
\begin{aligned}
& \operatorname{Ln} Y t=\operatorname{LnY} 0+t \operatorname{Ln}(1+r) \\
& \operatorname{LnYt}=b 1+b 2
\end{aligned}
$$

Now considering only $\mathrm{b} 2$ for growth rate...

b2 $=\operatorname{Ln}(1+\mathrm{r})$

Antilog $\mathrm{b} 2=1+\mathrm{r}$

$\mathrm{r}=$ Antilog $\mathrm{b} 2-1$

"b2 (Beta)" is instantaneous growth rate i.e. at a point of time

" $\mathrm{r}$ " is annual compounding growth rate (ACGR) i.e. over a period of time.

Estimating Equation: With the help of the equation above, we can arrive at estimates of $\mathrm{a} \& \mathrm{~b}$

$$
\operatorname{Ln} \mathrm{Yt}=\mathrm{a}+\mathrm{bt}+\mu \mathrm{t}
$$

There are three purposes of estimating the regression equation:

- To obtain estimators of a \& b.

- To ascertain the predicted dependent variable $Y_{t}$ with the help of independent variable $\mathrm{X}$ this is ' $\mathrm{t}$ ' in this case.

- To eliminate the error term. 
20 | PRAGATI: Journal of Indian Economy, Volume 3, Issue 2

\subsection{Results and Analysis: Growth Trends in Macro-Variables}

In this section we have analysed the results of macro level analysis. In this context, we have calculated the growth and trends for production, consumptions, exports and imports by semi-log equations. Results and analyses have been presented with the help of regression statistics and graphical analysis.

\subsection{Growth and trend for aggregate production}

In this section, we calculate the growth and trend for aggregate production of steel industry at economy level. Tables 1(a) to 1(d) show the results of regression and ANOVA, along with residual output. Here, the R square value is 0.991 , which suggests that our regression model is a good fit.

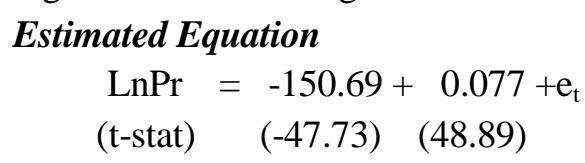

Table 1(a): Regression Statistics

\begin{tabular}{|l|c|}
\hline Multiple R & 0.995429826 \\
\hline R Square & 0.990880538 \\
\hline Adjusted R Square & 0.990466017 \\
\hline Standard Error & 0.053436881 \\
\hline Observations & 24 \\
\hline
\end{tabular}

Table 1(b): ANOVA

\begin{tabular}{|l|c|c|c|c|c|}
\hline Output & Df & SS & MS & F & Significance F \\
\hline Regression & 1 & 6.825 & 6.8258 & 2390.4229 & $6.12745 \mathrm{E}-24$ \\
\hline Residual & 22 & 0.0628 & 0.0028 & & \\
\hline Total & 23 & 6.8886 & & & \\
\hline
\end{tabular}

Table 1(c): Coefficients

\begin{tabular}{|l|c|c|c|c|}
\hline Variables & Coefficients & Standard Error & t-stat & P-value \\
\hline Intercept & -150.6946559 & 3.157069335 & -47.73245056 & $1.03406 \mathrm{E}-23$ \\
\hline Years & 0.077042355 & 0.001575768 & 48.8919514 & $6.12745 \mathrm{E}-24$ \\
\hline
\end{tabular}


Table 1(d): Residual Output

\begin{tabular}{|c|c|c|c|c|}
\hline Observation & Predicted LnPR & Residuals & $\begin{array}{c}\text { Predicted } \\
\text { Production }\end{array}$ & $\begin{array}{c}\text { Actual } \\
\text { Production }\end{array}$ \\
\hline 1 & 2.773716179 & -0.11808271 & 16.01804949 & 14.234 \\
\hline 2 & 2.850758535 & -0.024273659 & 17.3009002 & 16.886 \\
\hline 3 & 2.92780089 & -0.093176777 & 18.68649163 & 17.024 \\
\hline 4 & 3.004843246 & -0.004869978 & 20.18305207 & 20.085 \\
\hline 5 & 3.081885601 & 0.108302642 & 21.79946877 & 24.293 \\
\hline 6 & 3.158927957 & 0.111553114 & 23.54534077 & 26.324 \\
\hline 7 & 3.235970312 & 0.075302362 & 25.43103585 & 27.42 \\
\hline 8 & 3.313012668 & 0.003280207 & 27.46775215 & 27.558 \\
\hline 9 & 3.390055023 & 0.027507713 & 29.66758463 & 30.495 \\
\hline 10 & 3.467097379 & 0.009702097 & 32.04359689 & 32.356 \\
\hline 11 & 3.544139734 & -0.036302655 & 34.60989881 & 33.376 \\
\hline 12 & 3.621182089 & -0.005787725 & 37.38173026 & 37.166 \\
\hline 13 & 3.698224445 & 0.008224753 & 40.37555166 & 40.709 \\
\hline 14 & 3.7752668 & -0.002207056 & 43.6091417 & 43.513 \\
\hline 15 & 3.852309156 & -0.011438495 & 47.10170292 & 46.566 \\
\hline 16 & 3.929351511 & 0.032013887 & 50.87397577 & 52.529 \\
\hline 17 & 4.006393867 & 0.020296214 & 54.94836174 & 56.075 \\
\hline 18 & 4.083436222 & -0.037511893 & 59.34905641 & 57.164 \\
\hline 19 & 4.160478578 & -0.055787723 & 64.10219314 & 60.624 \\
\hline 20 & 4.237520933 & -0.008922323 & 69.23599824 & 68.621 \\
\hline 21 & 4.314563289 & 0.015762074 & 74.78095862 & 75.969 \\
\hline 22 & 4.391605644 & 0.011215773 & 80.7700028 & 81.681 \\
\hline 23 & 4.468648 & 0.004988796 & 87.23869649 & 87.675 \\
\hline 24 & 4.545690355 & -0.029788637 & 94.22545378 & 91.46 \\
\hline
\end{tabular}

The Annual compound growth rate (ACGR) of production of steel industry is $8 \%$ over the time and t-statistic value of intercept and slope are (-47.73) and (48.89) respectively. This variable is statistically significant $(t>2)$. This implies that the production of the steel industry is growing at $8 \%$ over period (1992-2015). 
Moreover, the overall ACGR for production is $8 \%$ for the entire 24 year-period. It is closely related to the instantaneous growth rate of $7.7 \%$ p.a derived from the semi-log equation.

Figure 1 below presents the trend in aggregate production of steel for India during 1992-2015. It can be observed that the level of production was low at the beginning, but over the 24-year period there was a definite trend of production growing at a positive rate. This consists with the findings from the equation, wherein the productions were found to be growing at a rate of $8 \%$ p.a. during 1992-2015.

Figure 1: Trends in the Aggregate Production in Steel in India during the 1992-2015

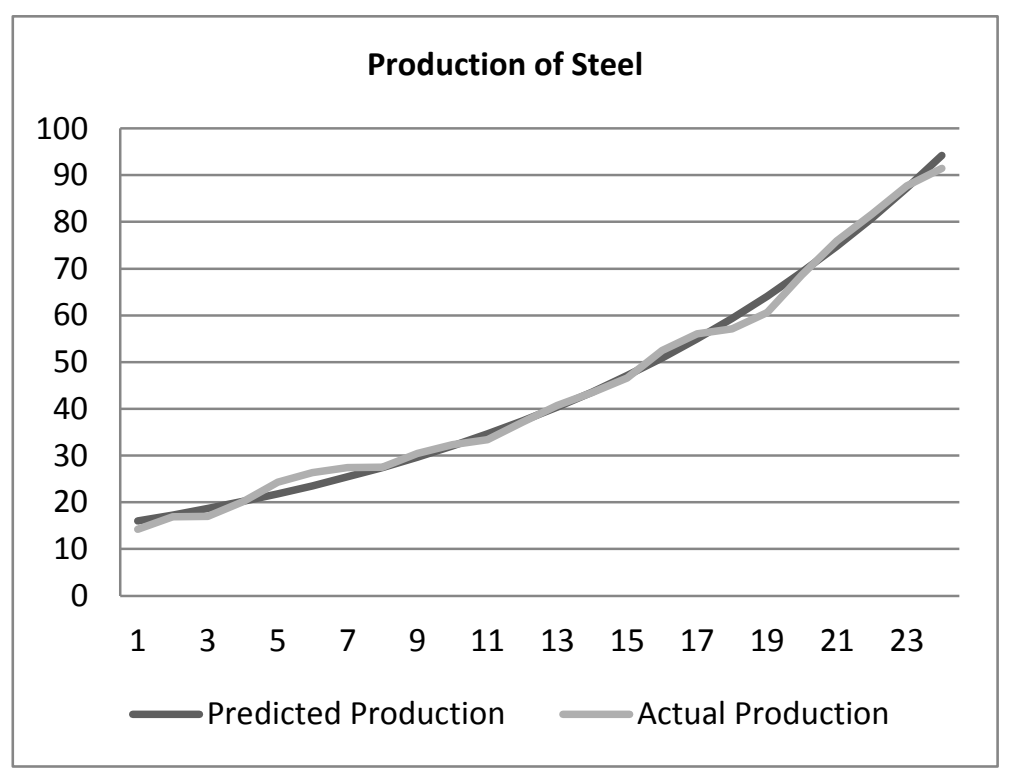

It can be seen from Figure 1 that predicted production and actual production are almost same over the time. We found minor difference in the year 1994, 1996 and 2010. In the year 1994 actual production is low to the predicted production, after that actual production started to increase. In 1995 actual and predicted production were same and after that actual production started to increase up to 1997. Since 1997 actual production is higher as compared to predicted production and it started to decrease from 1999. From 1999 to 2009, actual and predicted production were the same. In 2009 actual production started to decrease as compared to predicted production. From 2011 to 2015 predicted and actual production was same. We found minor difference between predicted and actual 
production of the steel industry between different times. Therefore, predicted production fits to show the trend in actual production.

\subsection{Growth and trends for aggregate consumption}

In this section, we calculate the growth trend for aggregate consumption of steel industry at economy level. Tables 2(a) to 2(d) show the results of regression and ANOVA, along with residual output. The $\mathrm{R}$ square value is 0.9866 , which suggest that our regression fit the data very well.

\section{Estimated Equation}

$$
\begin{array}{lcc}
\mathrm{LnCo} & =-146.086 & 0.07468 \\
(\mathrm{t}-\mathrm{stat}) & (-39.33) & (40.29)
\end{array}
$$

Annual compound growth rate (ACGR) of consumption of steel industry is $7.75 \%$ and t-statistic value of intercept and slope are (-39.34) and (40.29) respectively. This variable is statistically significant $(t>2)$. This employs that consumption of the steel industry is growing at 7.75\% over the period (1992-2015). Moreover, the overall ACGR for consumption is $7.75 \%$ for the entire 24 -year period. It is very close to the instantaneous growth rate of $7.46 \%$ p.a. derived from the semi-log equation. In fact, we can say both rates are almost same.

Table 2(a): Regression Statistics

\begin{tabular}{|l|c|}
\hline Multiple R & 0.993292767 \\
\hline R Square & 0.986630522 \\
\hline Adjusted R Square & 0.986022818 \\
\hline Standard Error & 0.062859843 \\
\hline Observations & 24 \\
\hline
\end{tabular}

Table 2(b): ANOVA

\begin{tabular}{|l|c|c|c|c|c|}
\hline Output & Df & SS & MS & F & Significance F \\
\hline Regression & 1 & 6.415187416 & 6.415187416 & 1623.539152 & $4.12793 \mathrm{E}-22$ \\
\hline Residual & 22 & 0.086929917 & 0.00395136 & & \\
\hline Total & 23 & 6.502117333 & & & \\
\hline
\end{tabular}

Table 2(c): Coefficients

\begin{tabular}{|l|c|c|c|c|}
\hline Variables & Coefficients & Standard Error & t Stat & P-value \\
\hline Intercept & -146.0860864 & 3.713781171 & -39.33621279 & $6.95622 \mathrm{E}-22$ \\
\hline Years & 0.074688847 & 0.001853636 & 40.29316508 & $4.12793 \mathrm{E}-22$ \\
\hline
\end{tabular}


24 | PRAGATI: Journal of Indian Economy, Volume 3, Issue 2

Table 2(d): Residual Output

\begin{tabular}{|c|c|c|c|c|}
\hline Observation & $\begin{array}{c}\text { Predicted } \\
\text { LnCO }\end{array}$ & Residuals & $\begin{array}{c}\text { Predicted } \\
\text { Consumption }\end{array}$ & $\begin{array}{c}\text { Actual } \\
\text { Consumption }\end{array}$ \\
\hline 1 & 2.694096485 & 0.002960174 & 14.79214779 & 14.836 \\
\hline 2 & 2.768785332 & -0.008079432 & 15.93926134 & 15.811 \\
\hline 3 & 2.843474179 & -0.06378572 & 17.17533218 & 16.114 \\
\hline 4 & 2.918163026 & 0.054812261 & 18.50725886 & 19.55 \\
\hline 5 & 2.992851873 & 0.114868903 & 19.94247487 & 22.37 \\
\hline 6 & 3.06754072 & 0.080655097 & 21.48899018 & 23.294 \\
\hline 7 & 3.142229566 & 0.027792092 & 23.15543593 & 23.808 \\
\hline 8 & 3.216918413 & -0.009710393 & 24.95111257 & 24.71 \\
\hline 9 & 3.29160726 & -0.020214889 & 26.88604181 & 26.348 \\
\hline 10 & 3.366296107 & -0.046706546 & 28.97102252 & 27.649 \\
\hline 11 & 3.440984954 & -0.090274174 & 31.21769101 & 28.523 \\
\hline 12 & 3.5156738 & -0.092160612 & 33.63858598 & 30.677 \\
\hline 13 & 3.590362647 & -0.090255511 & 36.2472185 & 33.119 \\
\hline 14 & 3.665051494 & -0.071114787 & 39.05814738 & 36.377 \\
\hline 15 & 3.739740341 & -0.015662676 & 42.08706046 & 41.433 \\
\hline 16 & 3.814429188 & 0.031090701 & 45.35086217 & 46.783 \\
\hline 17 & 3.889118035 & 0.064526646 & 48.86776783 & 52.125 \\
\hline 18 & 3.963806881 & -0.005835842 & 52.65740537 & 52.351 \\
\hline 19 & 4.038495728 & 0.044771034 & 56.74092481 & 59.339 \\
\hline 20 & 4.113184575 & 0.082858807 & 61.14111634 & 66.423 \\
\hline 21 & 4.187873422 & 0.075102186 & 65.88253752 & 71.021 \\
\hline 22 & 4.262562269 & 0.03447821 & 70.9916503 & 73.482 \\
\hline 23 & 4.337251116 & -0.031903062 & 76.49696873 & 74.095 \\
\hline 24 & 4.411939962 & -0.068212466 & 82.42921808 & 76.994 \\
\hline
\end{tabular}

Figure 2 below presents the trends in aggregate consumption for India during 19922015. It can be observed that the level consumption was low at the beginning, but over the 24-year period there was a definite trend of consumption growing at a positive rate. This 
consists of the findings wherein the consumption was found to be growing at a rate of $7.75 \%$ p.a. during $1992-2015$.

Figure 2: Trends in the Aggregate Consumption in Steel in India during the 1992-2015

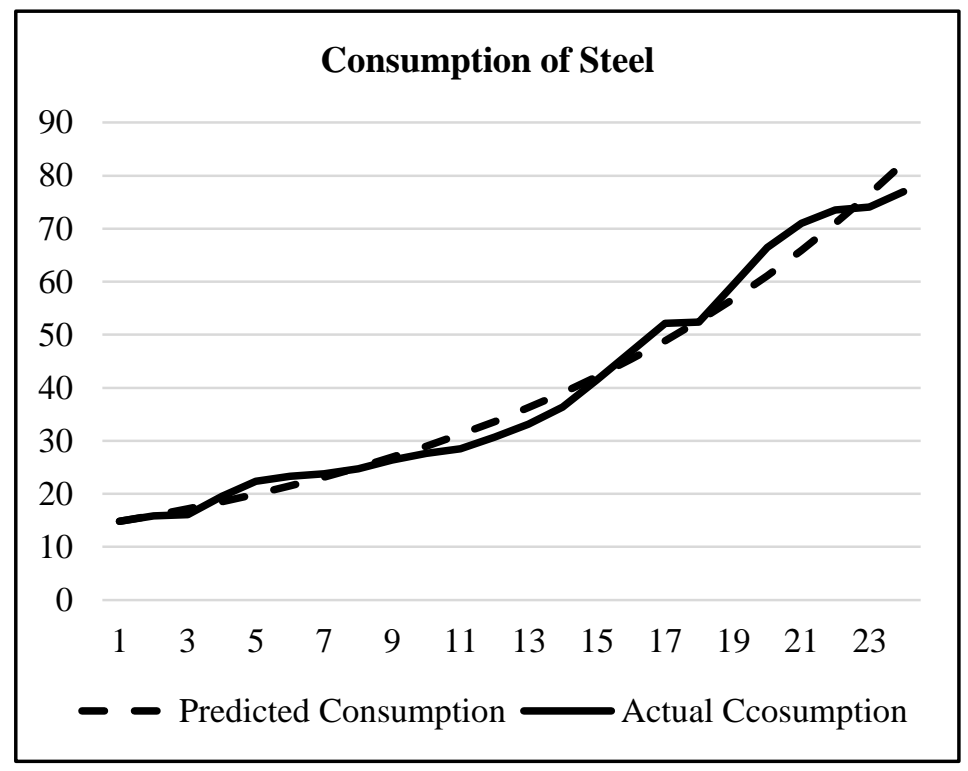

From Figure 2, it can be seen that predicted consumption and actual consumption are alike. There are minor differences during some time period. From 1995 actual consumption started to increase and from 1996, it started to decrease up to 1998 than predicted consumption. From 1998 to 2001, actual and predicted consumption are same. From 2001 to 2006, the actual consumption is lower than predicted consumption. From 2007 to 2009, actual consumption is higher. In 2009, actual and predicted consumption are same. After that, actual consumption started to increase up to 2014 and then it started to decrease. But the differences between actual and predicted consumption were very minute. Therefore, predicted consumption fits to show the trend in actual consumption.

\subsection{Growth and trends for aggregate export}

In this section, we calculate the growth and trends for aggregate export of steel industry at economy level. Tables 3(a) to 3(d) show the results of regression and ANOVA, along with residual output. The $\mathrm{R}$ square value is 0.7707 , which suggest that our regression fits the data reasonably well. 
26 | PRAGATI: Journal of Indian Economy, Volume 3, Issue 2

\section{Estimated Equation}

$$
\begin{aligned}
& \mathrm{LnX}=-186.010+0.0933+\mathrm{e}_{\mathrm{t}} \\
& (\mathrm{t}-\mathrm{stat}) \quad(-8.55) \quad(8.60)
\end{aligned}
$$

Annual compound growth rate (ACGR) of export of steel industry is $9.78 \%$ and tstatistic value of intercept and slope are (-8.53) and (8.6) respectively. This variable is statistically significant $(t>2)$. This employ that export of the steel industry is growing at 9.78\% over the period (1992-2015). Moreover, the overall ACGR for export is 9.78\% for the entire 24-year period. It is very close to the instantaneous growth rate of $9.33 \%$ p.a derived from the semi-log equation.

Table 3(a): Regression Statistics

\begin{tabular}{|l|c|}
\hline Multiple R & 0.877918444 \\
\hline R Square & 0.770740794 \\
\hline Adjusted R Square & 0.760319921 \\
\hline Standard Error & 0.368066835 \\
\hline Observations & 24 \\
\hline
\end{tabular}

Table 3(b): ANOVA

\begin{tabular}{|l|c|c|c|c|c|}
\hline Output & Df & SS & MS & F & Significance F \\
\hline Regression & 1 & 10.01976686 & 10.01976686 & 73.96125001 & $1.74059 \mathrm{E}-08$ \\
\hline Residual & 22 & 2.980410296 & 0.135473195 & & \\
\hline Total & 23 & 13.00017716 & & & \\
\hline
\end{tabular}

Table 3(c): Coefficients

\begin{tabular}{|l|c|c|c|c|}
\hline Variables & Coefficients & Standard Error & t Stat & P-value \\
\hline Intercept & -186.0101226 & 21.74551541 & -8.553953265 & $1.90866 \mathrm{E}-08$ \\
\hline Years & 0.093342599 & 0.010853699 & 8.600072674 & $1.74059 \mathrm{E}-08$ \\
\hline
\end{tabular}

Figure 3 presents the trend in aggregate export for India during 1992-2015. It can be observed that the level export was low at the beginning, but over the 24-year period there was a drastic change in the trend in export. This consists of the findings from the equation above, wherein the exports were found to be growing at a rate of $9.78 \%$ p.a. during $1992-$ 2015. 
Table 3(d): Residual Output

\begin{tabular}{|c|c|c|c|c|}
\hline Observation & Predicted LnX & Residuals & Predicted Export & Actual Export \\
\hline 1 & -0.071665758 & -0.928006583 & 0.93084197 & 0.368 \\
\hline 2 & 0.021676841 & -0.301390743 & 1.02191349 & 0.756 \\
\hline 3 & 0.115019439 & -0.056750531 & 1.121895246 & 1.06 \\
\hline 4 & 0.208362038 & -0.265991151 & 1.231658996 & 0.944 \\
\hline 5 & 0.301704637 & -0.001600044 & 1.352161789 & 1.35 \\
\hline 6 & 0.395047236 & 0.111770367 & 1.484454309 & 1.66 \\
\hline 7 & 0.488389835 & 0.171200562 & 1.629690036 & 1.934 \\
\hline 8 & 0.581732433 & 0.038844054 & 1.789135305 & 1.86 \\
\hline 9 & 0.675075032 & 0.348095061 & 1.964180347 & 2.782 \\
\hline 10 & 0.768417631 & 0.214035303 & 2.156351409 & 2.671 \\
\hline 11 & 0.86176023 & 0.134819333 & 2.367324063 & 2.709 \\
\hline 12 & 0.955102829 & 0.552745228 & 2.598937814 & 4.517 \\
\hline 13 & 1.048445427 & 0.601558447 & 2.853212143 & 5.207 \\
\hline 14 & 1.141788026 & 0.406837747 & 3.13236411 & 4.705 \\
\hline 15 & 1.235130625 & 0.333693605 & 3.438827688 & 4.801 \\
\hline 16 & 1.328473224 & 0.328229881 & 3.775274985 & 5.242 \\
\hline 17 & 1.421815823 & 0.202904713 & 4.144639541 & 5.077 \\
\hline 18 & 1.515158421 & -0.025179949 & 4.550141909 & 4.437 \\
\hline 19 & 1.60850102 & -0.429538379 & 4.995317732 & 3.251 \\
\hline 20 & 1.701843619 & -0.410684453 & 5.484048573 & 3.637 \\
\hline 21 & 1.795186218 & -0.271742019 & 6.020595759 & 4.588 \\
\hline 22 & 1.888528817 & -0.208073417 & 6.609637535 & 5.368 \\
\hline 23 & 1.981871415 & -0.192615076 & 7.256309856 & 5.985 \\
\hline 24 & 2.075214014 & -0.353161957 & 7.966251167 & 5.596 \\
\hline & & & & \\
\hline
\end{tabular}

From Figure 3, it can be seen that there is a large difference between predicted and actual export. From 1992 to 1999, there is a minor difference between actual and predicted export. After this time period actual export started to increase up to 2001 and started to decrease up to 2002. From 2002 to 2005, the actual exports are increasing drastically than predicted exports. After 2005, the export also started to decrease drastically up to 2010. 
After that, exports started to increase up to 2014 and from 2014, they started to decrease. We found actual and predicted export were same in 1994, 1996, 1999 and 2009 only, and a large increasing and decreasing gap between actual and predicted export between different times. There could be so may reason of this gap. Export affected by the international pricing policies, export duties and competition in the international market. Therefore, predicted exports do not fit to show the trend in actual exports. This shows volatility in exports.

Figure 3: Trends in the Aggregate Exports of Steel in India during the 1992-2015

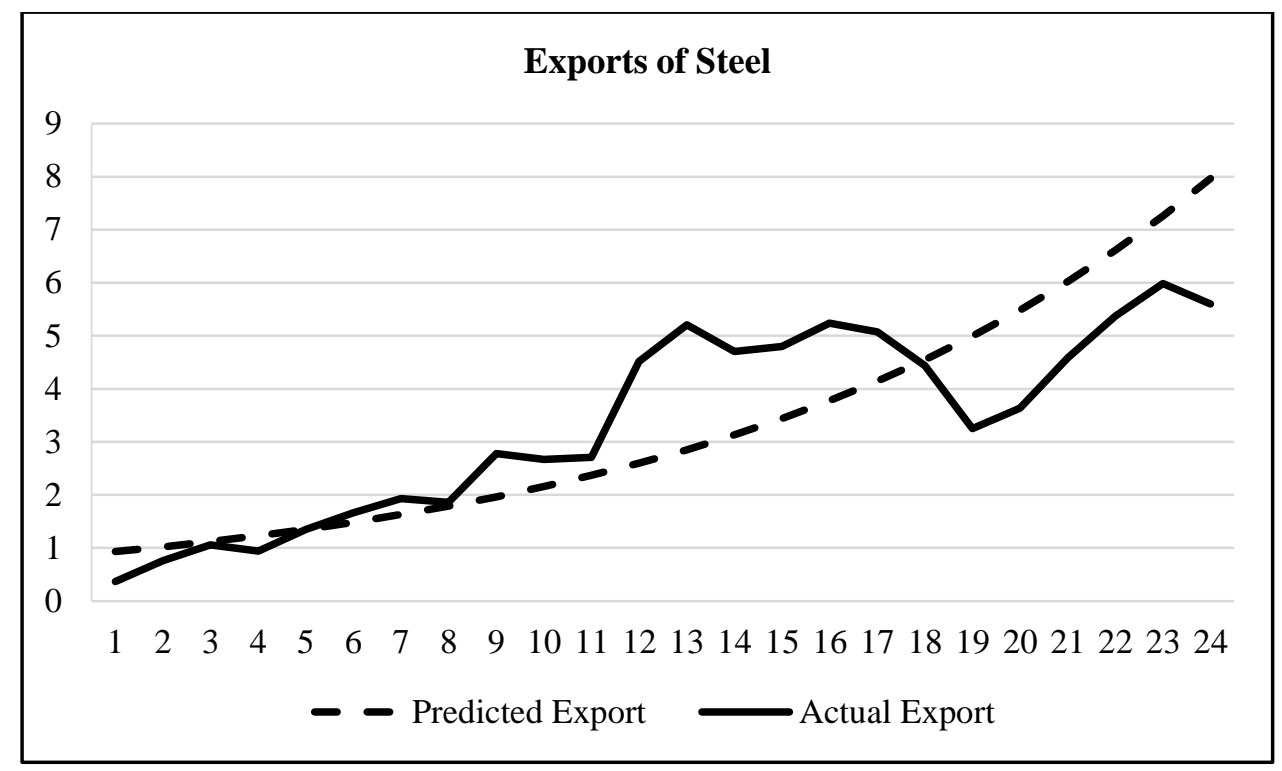

\subsection{Growth and Trends for Aggregate Import}

In this section, we calculate the growth and trends for aggregate import of steel industry at economy level. Tables 4(a) to 4(d) show the results of regression and ANOVA, along with residual output. Here, the R square value is 0.8457 , which suggest that our regression fit the data well.

\section{Estimated Equation}

$$
\begin{aligned}
& \mathrm{LnM}=-199.51+0.10008+e_{t} \\
& (t-s t a t) \quad(-10.927)(10.98)
\end{aligned}
$$

Annual compound growth rate (ACGR) of import of steel industry is $10.53 \%$ and tstatistic value of intercept and slope are (-10.93) an (10.98) respectively. This variable is statistically significant $(t>2)$. This employ that import of the steel industry is growing at 
the rate of $10.53 \%$ over the period. Moreover, the overall ACGR for export is $10.53 \%$ for the entire 24-year period. It is very close to the instantaneous growth rate of $10.98 \%$ p.a derived from the semi-log equation.

Table 4(a): Regression Statistics

\begin{tabular}{|l|c|}
\hline Multiple R & 0.919639305 \\
\hline R Square & 0.845736451 \\
\hline Adjusted R Square & 0.838724472 \\
\hline Standard Error & 0.309042198 \\
\hline Observations & 24 \\
\hline
\end{tabular}

Table 4(b): ANOVA

\begin{tabular}{|l|c|c|c|c|c|}
\hline Output & df & SS & MS & F & Significance F \\
\hline Regression & 1 & 11.51940317 & 11.51940317 & 120.613081 & $2.13712 \mathrm{E}-10$ \\
\hline Residual & 22 & 2.101155759 & 0.09550708 & & \\
\hline Total & 23 & 13.62055893 & & & \\
\hline
\end{tabular}

Table 4(c): Coefficients

\begin{tabular}{|l|c|c|c|c|}
\hline Variables & Coefficients & Standard Error & t Stat & P-value \\
\hline Intercept & -199.5122928 & 18.25831949 & -10.92719912 & $2.34866 \mathrm{E}-10$ \\
\hline Years & 0.100084326 & 0.009113157 & 10.98239869 & $2.13712 \mathrm{E}-10$ \\
\hline
\end{tabular}

Figure 4 presents the trend in aggregate import for India during 1992-2015. It can be observed that the level import was low at the beginning, but over the 24-year period there was also a drastic change in the trend in export. This consists of the findings from the equation wherein the exports were found to be growing at a rate of $10.53 \%$ p.a. during 1992-2015. From Figure 4, we found a large gap between predicted and actual import. From 1992 to 1994 actual and predicted imports are almost same. After 1994 actual imports starts to increase upto 1995 and then start to decrease upto 1998. In 1998 actual and predicted imports are same and after 1998 actual imports starts to decrease drastically upto 2006. In 2006 actual and predicted imports are found same. After 2006, there is a drastic variation in the increasing and decreasing of actual imports and predicted imports which carries on up to 2013. 
30 | PRAGATI: Journal of Indian Economy, Volume 3, Issue 2

Table 4(d): Residual Output

\begin{tabular}{|c|c|c|c|c|}
\hline Observation & Predicted LnM & Residuals & Predicted Import & Actual Import \\
\hline 1 & -0.14431527 & 0.113856063 & 0.865614803 & 0.97 \\
\hline 2 & -0.044230944 & 0.177887329 & 0.95673298 & 1.143 \\
\hline 3 & 0.055853382 & 0.056582047 & 1.057442632 & 1.119 \\
\hline 4 & 0.155937708 & 0.417862715 & 1.168753397 & 1.775 \\
\hline 5 & 0.256022034 & 0.224550546 & 1.291781191 & 1.617 \\
\hline 6 & 0.35610636 & 0.133699896 & 1.427759397 & 1.632 \\
\hline 7 & 0.456190686 & 0.043371745 & 1.578051229 & 1.648 \\
\hline 8 & 0.556275012 & -0.378965997 & 1.744163397 & 1.194 \\
\hline 9 & 0.656359338 & -0.13875673 & 1.927761217 & 1.678 \\
\hline 10 & 0.756443664 & -0.356996629 & 2.130685299 & 1.491 \\
\hline 11 & 0.85652799 & -0.539529864 & 2.354970005 & 1.373 \\
\hline 12 & 0.956612317 & -0.447989116 & 2.602863842 & 1.663 \\
\hline 13 & 1.056696643 & -0.495368037 & 2.876852005 & 1.753 \\
\hline 14 & 1.156780969 & -0.326919965 & 3.17968129 & 2.293 \\
\hline 15 & 1.256865295 & 0.202911843 & 3.514387633 & 4.305 \\
\hline 16 & 1.356949621 & 0.237780663 & 3.884326543 & 4.927 \\
\hline 17 & 1.457033947 & 0.493010501 & 4.293206745 & 7.029 \\
\hline 18 & 1.557118273 & 0.207783742 & 4.745127361 & 5.841 \\
\hline 19 & 1.657202599 & 0.341842006 & 5.244619002 & 7.382 \\
\hline 20 & 1.757286925 & 0.13943298 & 5.796689188 & 6.664 \\
\hline 21 & 1.857371251 & 0.068773413 & 6.406872556 & 6.863 \\
\hline 22 & 1.957455577 & 0.112566743 & 7.081286336 & 7.925 \\
\hline 23 & 2.057539903 & -0.361924294 & 7.826691687 & 5.45 \\
\hline 24 & 2.157624229 & 0.074538399 & 8.650561475 & 9.32 \\
\hline & & & & \\
\hline
\end{tabular}

In 2013 actual and predicted imports are same but there is a drastic decrease in actual imports up to 2014, and from 2014 the imports have started to increase drastically. We found actual and predicted imports are same in 1994, 1998, 2006 and 2013 with only a large increase and decrease exist between the actual and predicted imports at different times. There could be so many reasons for this gap. Imports are also affected by the 
international pricing policies, import duties and competitions in the international market and domestic consumption. Therefore, predicted imports sometimes do not match with the actual trend. This shows volatility in imports.

Figure 4: Trends in the Aggregate Import in India during the 1992-2015

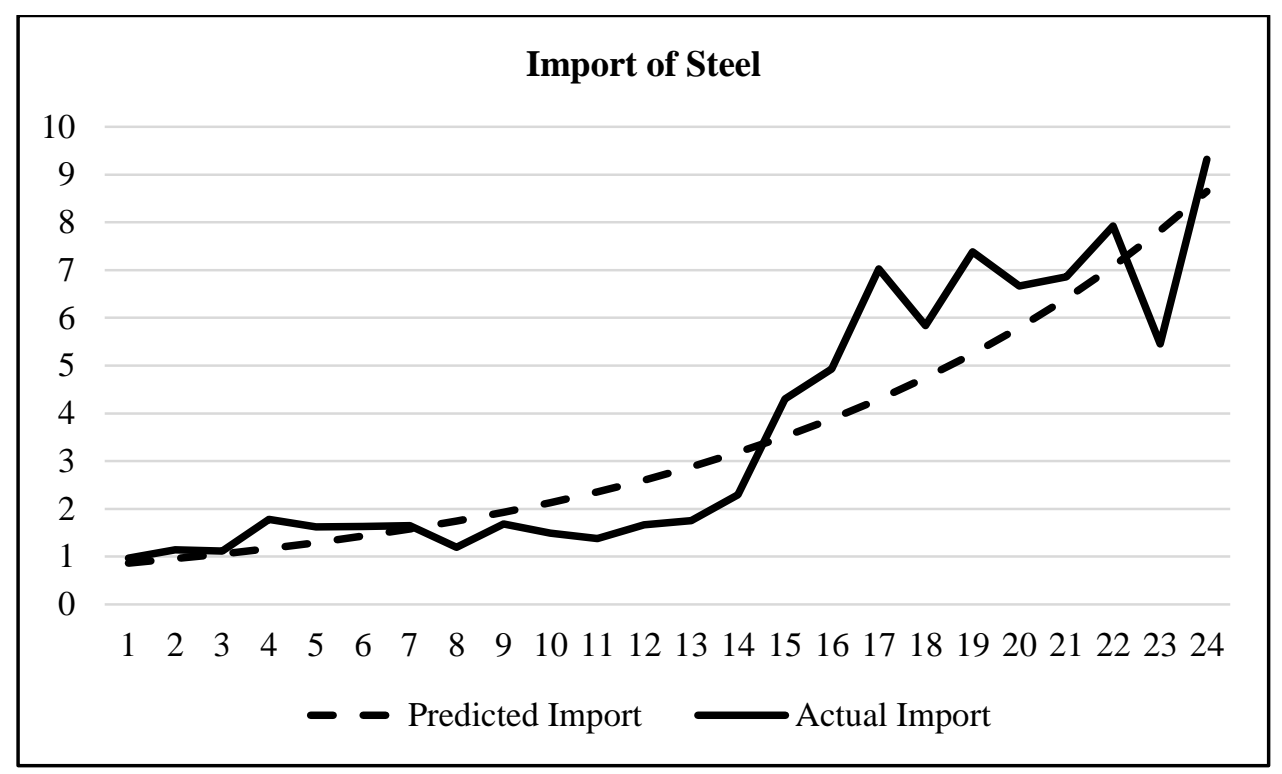

\subsection{Conclusion}

This paper presents a macro level analysis of steel industry. We have estimated the growth trend for production, consumption, exports and imports at the economy level by using a semi-log equation model. Firstly, we found that all variables are significantly related to a catch-all variable called 'time'. Secondly, we calculated the predicted value of all variables and compared them with the actual value by the graphic presentations. They closely follow each other in most cases. The regression analysis shows that production grew at $8 \%$ and consumption at $7.75 \%$ during the time period 1992-2015. Exports grew at $9.78 \%$ per annum and declined drastically after the year 2005. On the other hand, the imports grew at $10.53 \%$ and increased also drastically after 2005. It shows that after the year 2005, there could have been a change in the industrial policy. On the whole, we conclude that production and consumption increased over the time. Exports and imports also show an increasing trend but export trend is weaker than the import trend. This shows that systematic risk arises due to transaction exposure of volatility in foreign exchange 
32 | PRAGATI: Journal of Indian Economy, Volume 3, Issue 2

because we earned less Foreign Exchange (FE) and spent more on steel import in the form of Foreign Exchange. Since the time when FE rate regime has been liberalised, the FE rates have been very volatile and Rupee has been depreciating constantly. If a larger sum is spent on imports it implies that the foreign exchange risk is higher. However, since this is systematic risk it cannot be diversified.

\section{References}

Bhunia, A. (2005-06). A study of liquidity trends on private sector steel companies in India. Asian Journal of Management Research: 618-628.

Firoj, A. S. (2014). Long term perspectives for Indian steel industry. Economic Research Unit, Ministry of Steel.

Gibb, Allan. (2003). Small and Medium Enterprise development. Journal of Small Business and Enterprise Development, 7(3).

Kulkarni, S. (2015). A brief report on iron and steel industry in India. ASA \& Associate LLP, WWW.asa.in

Nair, Anil. (2006). Collaborative logistics can make SME clusters competitive: CII Report on SME cluster logistics. SME World Journal of Financial Express, May-July.

Panday, Mrijunay Kumar. (2008). Indian steel industry in a global perspective. The ICFAI University Journal Entrepreneurship Development, V(4).

Parmila, S., Kumar, K. \& Karmakar, A. (2016). A Study On Steel Industries In India. International Journal of Research in Humanities, Arts and Literature, 4(6): 43-54. 